\title{
Yeast Cell Wall Bound Proteolytic Enzymes
}

\author{
Masami Kusunose, Toshihiro NaKanishi, Noshi Minamiura \\ and Takehiko YAMAMOTO \\ Faculty of Science, Osaka City University, Sumiyoshi-ku, Osaka 558, Japan \\ Received February 25, 1980
}

\begin{abstract}
Nearly all the amino group-producing activity of the autolysate of cells of Saccharomyces sake was recovered in the cell wall fraction obtained from the autolysis residue. The activity of the cell wall fraction was not lost even after repeated use.

The proteolytic activity of the fraction was not solubilized by incubation with detergents, disruption with cell mill or by freezing and thawing method, but was solubilized to some extent by incubation with a commercial yeast cell-lytic enzyme preparation.

The cell wall fraction hydrolysed casein to about $50 \%$. When casein was previously treated with certain proteinases, more than $60 \%$ was digested. The activity of the fraction was significantly increased by the addition of $\mathrm{Zn}^{2+}$ while it was decreased by several proteolytic enzyme inhibitors. The interesting fact was that in the presence of EDTA the cell wall fraction showed only carboxypeptidase-like activity, and attacked the oxidized insulin B-chain to release two amino acids from the carboxyl terminal in known order.
\end{abstract}

Many papers have been published on peptidases of yeast cells. ${ }^{1,2)}$ However, the studies so far reported were on the enzymes in the supernatants of autolysate or in disrupted debris of yeast cells.

Recently, we observed that the major peptidase activity in the autolysate of cells of Saccharomyces sake was recovered in the residue after autolysis. The washed residue consisted exclusively of cell wall of the yeast.

The present paper describes some properties of the proteolytic enzyme bound to the cell wall fraction of Saccharomyces sake obtained after autolysis of the cells.

\section{MATERIALS AND METHODS}

Yeast used. A strain of Saccharomyces sake was cultured with shaking at $28^{\circ} \mathrm{C}$ using $500 \mathrm{ml}$ flasks containing $80 \mathrm{ml}$ of the medium consisted of $7.5 \%$ glucose, $1.5 \%$ polypeptone, $0.5 \%$ yeast extract (Difco Laboratories), $0.3 \% \mathrm{~K}_{2} \mathrm{HPO}_{4}$, and $0.03 \% \mathrm{MgSO}_{4} \cdot 7 \mathrm{H}_{2} \mathrm{O}$ in city water, pH 5.2. After 4 day culture, the yeast cells were collected and washed several times with deionized water by using a centrifuge.

Autolysis of the yeast cells and isolation of the cell wall fraction. The washed yeast cells were mixed with a half volume of ethyl acetate and incubated at $25^{\circ} \mathrm{C}$.
After 3 day incubation, the mixture was centrifuged and the residue was washed several times by alternate use of $2.5 \mathrm{M}$ sodium chloride and distilled water supplemented with $0.05 \% \mathrm{NaN}_{3}$ followed by dialysis against distilled water in the cold until negative ninhydrin reaction was obtained for the dialysate. The dialysed residue was lyophilized. The yield of lyophilized preparation was nearly $50 \%$ of the yeast cells on a dry weight basis. The preparation was used as an enzyme in the experiments described below.

Substrates used. Cow milk casein, soy bean protein, ovalbumin, bovine serum albumin, zein, and hemoglobin were used as protein substrate. Oxidized insulin B-chain which was prepared according to the method of Griffin, et al. ${ }^{37}$ and several synthetic peptides obtained from Protein Research Foundation and Sigma Chemical Co, were used for examination of specificity of the cell wall fraction.

The substrates used for assay of the amino groupproducing activity was prepared as described below.

Assay of amino group-producing activity. Cow milk casein (Wako Pure Chemical Industries Ltd.) was washed with $50 \%$ cold ethanol to remove soluble impurities in the casein and then dried in vacuo. Twenty grams of the washed casein were dissolved in $50 \mathrm{ml}$ of $0.1 \mathrm{~N} \mathrm{NaOH}$ by heating at $60^{\circ} \mathrm{C}$ for about 10 min, and diluted with $400 \mathrm{ml}$ of distilled water. This solution was incubated with $2.0 \mathrm{mg}$ of Streptomyces alkalophilic proteinase ${ }^{4)}$ at $30^{\circ} \mathrm{C}, \mathrm{pH} 11.0$, for $5 \mathrm{hr}$ whereby the degree of hydrolysis of the casein attained 
to about $10 \%$. This mixture was heated in boiling water for $20 \mathrm{~min}$ to inactivate the enzyme added, cooled, $\mathrm{pH}$ was adjusted to 5.6 with acetic acid, and the total volume of the mixture was brought up to $500 \mathrm{ml}$ with distilled water (designated as peptide mixture).

For assay of the amino group-producing activity, $0.5 \mathrm{ml}$ of enzyme (a suspension of the cell wall fraction obtained above) was incubated with $0.5 \mathrm{ml}$ of the peptide mixture at $30^{\circ} \mathrm{C}$. After appropriate intervals of time, aliquots of the mixture were taken, diluted with $0.02 \mathrm{~N} \mathrm{HCl}$ to inactivate the enzyme, and the amino groups produced were measured by the method of Yemm and Cocking. ${ }^{5}$ ) One unit of the enzyme activity was defined as the enzyme amount that liberated on $\mu$ mol of amino groups as L-leucine per min under the conditions.

Assay of proteinase. The proteinase activity was assayed by the method reported previously, ${ }^{4}$ except that $\mathrm{pH}$ of the reaction mixture was adjusted to $\mathrm{pH} 5.8$. One unit of the enzyme activity was defined as the enzyme a mount that made the amount of casein equivalent to one $\mu \mathrm{mol}$ of tyrosine, trichloroacetic acid soluble in a minute at $30^{\circ} \mathrm{C}$.

Enzymes used. Streptomyces alkalophilic proteinase was prepared according to the method reported previously. ${ }^{4)}$ Bacillus subtilis neutral proteinase and trypsin were obtained from Seikagaku Kogyo Co., Ltd.; "Cellulosin", a mixed cellulolytic and hemicellulolytic enzymes from Aspergillus niger, and "Samprose", a commercial preparation of Rhizopus acid proteinase, were from Ueda Kagaku Kogyo Co., Ltd.; papain, from E. Merck Darmstadt (Germany); "Zymolyase$\left.60000^{*}{ }^{*} \sim 8\right)$ which has been reported to be effective for lysis of variable yeast cells was kindly supplied from Kirin Brewery Co., Ltd.

All the chemicals used were of reagent grade available commercially.

\section{RESULTS}

Distribution of proteolytic activity of the yeast cells after autolysis

An aliquot of autolysate of the yeast cells performed as described above was centrifuged and the residue was washed several times with each several volumes of distilled water. The supernatant and washings were combined, dialysed, and concentrated using a collodion bag. The enzyme activities of a suspension of the residue and the combined solution of the supernatant and washings are shown in Table $\mathrm{I}$, indicating that the major activity was observed in the washed residue.

\section{General properties of the washed residue}

The residue obtained from the autolysate of the yeast cells contained only $0.4 \%$ of nitrogen. The total sugar content of the residue estimated by phenol-sulfuric acid method ${ }^{9}$ was $94 \%$. The lyophilized preparation was readily dispersed in water, and upon incubation with trypsin over night at $30^{\circ} \mathrm{C}$ liberation of proteinous material nor loss of enzyme occurred. The residue was observed to consist of only the cell walls of the yeast under a microscope.

The amino group-producing and proteinase activities of the cell wall fraction were 2.2 and 0.07 units per gram preparation, respectively.

Table I. Proteolytic Activities of the Soluble and Residual Fractions of the Yeast Cell AutOLYSATE

The activity was expressed per one gram of the yeast cells as dry basis.

\begin{tabular}{ccc} 
Activity & $\begin{array}{c}\text { Soluble } \\
\text { fraction, } \\
\text { units }\end{array}$ & $\begin{array}{c}\text { Residual } \\
\text { fraction, } \\
\text { units }\end{array}$ \\
\hline $\begin{array}{c}\text { Amino group- } \\
\text { producing }\end{array}$ & 0.06 & 1.1 \\
Proteinase & 0.097 & 0.035 \\
\hline
\end{tabular}

\section{Solubilization of the enzyme activity from the} cell wall fraction

Various treatments were applied to the cell wall fraction to solubilize the enzyme. The fraction was suspended in solutions of several surface active agents $(0.2 \sim 1.5 \%$ of Triton $\mathrm{X}$ 100 , Tween 20 or sodium cholate) and reducing agents $\left(10^{-4} \sim 10^{-2} \mathrm{M} \quad \beta\right.$-mercaptoethanol or dithiothreitol) and incubated at $4^{\circ} \mathrm{C}$ and at pH $5.2 \sim 6.5$, for $24 \mathrm{hr}$, and the enzyme activities of the supernatant and precipitate were assayed. The result showed that none of the chemicals tested was effective for solubilization of the enzyme.

The disruption of the cell wall fraction was performed with Cell Mill (Vibrogen) using 10 to 50 mesh glass beads for $15 \mathrm{~min}$ in the cold. The cell walls were completely disrupted as observed under a microscope, but the enzyme activity was found to still remain in the precipitate after centrifugation of the milled mixture.

The effects of several enzyme preparations of 
commercial source was investigated. As shown in Table II, "Zymolyase-60000" " $\sim 8$ ' was found to be effective to some extent for liberation of the enzyme.

The solubilization of the enzyme by "Zymolyase-60000" was examined under several conditions. The coexistence of cholate accelerated the rate of the enzyme liberation, but the amount of the enzyme liberated was similar in the amount to that by "Zymolyase" treatment alone, as shown in Fig. 1.

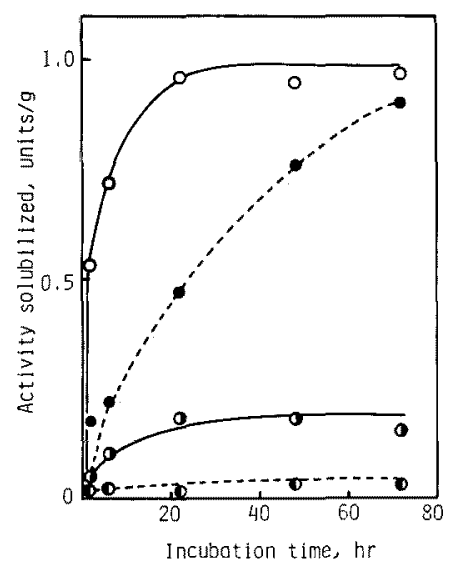

FIG. 1. Solubilization of the Amino Group-Producing Activity from the Cell Wall Fraction by Zymolyase.

One gram of the cell wall fraction was incubated with $5 \mathrm{mg}$ of "Zymolyase- 60000 " in total $25 \mathrm{ml}$ of $0.3 \%$ sodium cholate or water at pH $5.3 \sim 6.0$ and $30^{\circ} \mathrm{C}$. $\bigcirc$, Zymolyase + cholate; $\bullet$, zymolyase; $\mathbf{O}$, cholate; o, none.

Properties of the cell wall enzyme

1) $\mathrm{pH}$ - and temperature-activities. The $\mathrm{pH}-$ and temperature-activities were investigated using the peptide mixture as the substrate. The optimum $\mathrm{pH}$ for the amino group-producing activity was at $\mathrm{pH}$ values between $5.6 \sim$ 6.0. The activity at $\mathrm{pH} 4.6$ and 7.8 was a half of that at the optimum $\mathrm{pH}$. The enzyme activity was highest at $40^{\circ} \mathrm{C}$ in the enzyme reaction test for $20 \mathrm{hr}$.

2) Stabilities. The cell wall fraction was suspended in $0.1 \mathrm{M}$ buffer of various $\mathrm{pH}$ values between 3.5 and 9.0 , and incubated at $30^{\circ} \mathrm{C}$ for $24 \mathrm{hr}$. Then, the suspension was centri- fuged, the precipitate was washed twice with $0.05 \mathrm{M}$ acetate buffer, $\mathrm{pH} 5.6$, and the activities of the precipitate were assayed. The cell wall enzyme was stable in a $\mathrm{pH}$ region from 4.8 to 8.0. Also, the enzyme did not lose the activity at temperatures up to $40^{\circ} \mathrm{C}$ on incubation for $1 \mathrm{hr}$ at $\mathrm{pH}$ 5.6.

Effects of various metal ions on enzyme activity The effects of various metal ions on the enzyme activity were examined. In the experiment, the cell wall fraction was previously incubated with $2 \mathrm{~mm}$ EDTA at $30^{\circ} \mathrm{C}$ for $20 \mathrm{hr}$, and then metal salts were added to the mixture to make the concentration $4 \mathrm{~mm}$. By incubation with EDTA, the enzyme activity on the peptide mixture was decreased nearly a half. On the other hand, the addition of $\mathrm{Zn}^{2+}$ (acetate) increased the activity by about $50 \%$ (three fold as compared with that shown in the presence of EDTA) of the cell wall fraction. $\mathrm{Co}^{2+}$ slightly increased while $\mathrm{Cd}^{2+}, \mathrm{Fe}^{2+}$, $\mathrm{Cu}^{2+}, \mathrm{Pb}^{2+}, \mathrm{Fe}^{3+}$, and $\mathrm{Hg}^{2+}$ inhibited the enzyme activity in the increasing order, and the activity was only $13 \%$ by the addition of $\mathrm{Fe}^{3+}$ (chloride salt).

Effects of several inhibitors and reducing agents

The cell wall fraction was incubated with several inhibitors at $30^{\circ} \mathrm{C}$, and $1 \mathrm{hr}$ later, the remaining activity was assayed. The results are shown in Table III, indicating that the enzyme was inhibited by $p$-chloromercuribenzoic acid (PCMB) as well as by EDTA. The enzyme was not inhibited by diisopropylphosphofluoride (DFP) and phenylmethylsulfonyl fluoride (PMSF) so severely as done by PCMB and EDTA. No effects of $\beta$-mercaptoethanol and dithiothreitol on the activity were observed.

Hydrolysis of proteins by the cell wall fraction

The progressive curves of hydrolysis of casein at $\mathrm{pH} 5.6$ are shown in Fig. 2. The maximum degree of hydrolysis was nearly $50 \%$. The hydrolysis products were free amino acids and various small peptides. The addition of proteinase to the reaction mixture or the use of proteolytic digest of casein as 
TABle II. EfFects of Various Commercial

Enzyme Preparation on Solubilization of the Cell Wall Fraction Enzyme

The cell wall fraction $(100 \mathrm{mg})$ was incubated with the enzyme preparation indicated in $3 \mathrm{ml}$ of $0.05 \mathrm{M}$ acetate or phosphate buffer, $\mathrm{pH} 5.2 \sim 7.5$, at $30^{\circ} \mathrm{C}$. After $24 \mathrm{hr}$ incubation, the suspension was centrifuged, and the supernatant and residue were assayed for the enzyme activity.

\begin{tabular}{|c|c|c|c|}
\hline \multirow{2}{*}{ Enzyme added } & \multirow{2}{*}{$\begin{array}{c}\text { Concen- } \\
\text { tration } \\
(\%)\end{array}$} & \multicolumn{2}{|c|}{$\begin{array}{l}\text { Activity } \\
\text { (units/g) }\end{array}$} \\
\hline & & Sup. & Ppt. \\
\hline None & & 0.021 & 1.71 \\
\hline Trypsin & 0.16 & 0.340 & 1.37 \\
\hline Papain & 0.16 & 0.079 & 0.832 \\
\hline Neutral proteinase & 0.075 & 0.203 & 1.70 \\
\hline Cellulosin & 0.2 & 0.264 & 1.41 \\
\hline Samprose & 0.2 & 0.398 & 1.52 \\
\hline Zymolyase- 60000 & 0.2 & 1.12 & 1.34 \\
\hline
\end{tabular}

TABLE III. EFFECTS OF VARIOUS INHIBITORS ON ACTIVITY OF THE CELL Wall

FRACTION ENZYME

Fifty $\mathrm{mg}$ of the cell wall were incubated with the additions indicated, and the remaining activity was assayed after incubation for $1 \mathrm{hr}$ at $30^{\circ} \mathrm{C}$.

\begin{tabular}{lcc}
\hline \multicolumn{1}{c}{ Additions } & $\begin{array}{c}\text { Concentration } \\
(\mathrm{M})\end{array}$ & $\begin{array}{c}\text { Remaining } \\
\text { activity } \\
(\%)\end{array}$ \\
\hline None & $2 \times 10^{-3}$ & 100.0 \\
EDTA & $10^{-4}$ & 76.2 \\
DFP & $10^{-5}$ & 96.3 \\
PMSF & $10^{-4}$ & 85.0 \\
& $10^{-4}$ & 60.3 \\
PCMB & $10^{-3}$ & 22.0 \\
& $10^{-3}$ & 104.8 \\
$\beta$-Mercaptoethanol & $10^{-2}$ & 99.3 \\
Dithiothreitol & $10^{-4}$ & 104.0 \\
& $10^{-3}$ & 99.4 \\
\hline
\end{tabular}

substrate increased the rates as well as the degrees of hydrolysis. The effect of previous treatment of substrate proteins with proteinase on the hydrolysis rates and degrees was found to be greatly dependent upon the kind of protein used as substrate. It was noteworthy that the degree of hydrolysis of ovalbumin incubated initially with alkalophilic proteinase and then with the cell wall fraction, reached $60 \%$.

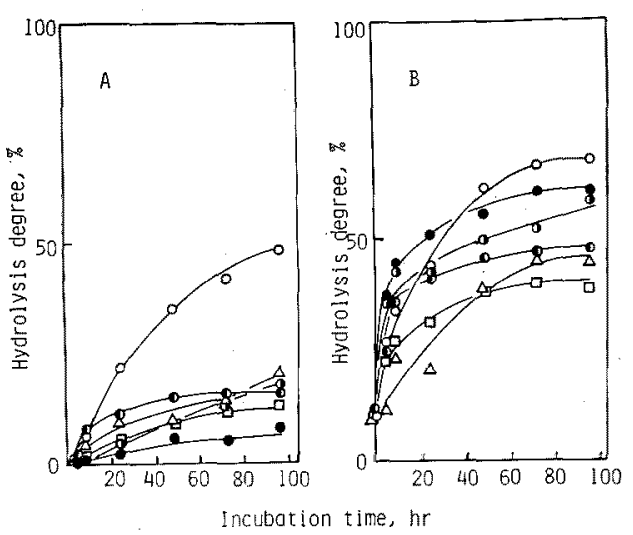

FIG. 2. Hydrolysis Curves of Various Proteins by the Cell Wall Fraction.

A. Various proteins $(350 \mathrm{mg})$ were incubated with $105 \mathrm{mg}$ of the cell wall in total $7 \mathrm{ml}$ at $\mathrm{pH} 5.6$.

B. Various proteins $(350 \mathrm{mg}$ ) were previously incubated with $1.0 \sim 2.0$ units of alkalophilic proteinase at $30^{\circ} \mathrm{C}, \mathrm{pH} 11.0$ for $2 \mathrm{hr}$. The $\mathrm{pH}$ of the hydrolysate were then adjusted to 5.6 and $105 \mathrm{mg}$ of the cell wall fraction was added to the mixture (total volume, $7 \mathrm{ml}$ ). $O$, Casein;, ovalbumin; $\boldsymbol{O}$, zein; $\mathbf{C}$, soy bean protein; $\triangle$, bovine serum albumin; $\square$, hemoglobin.

Repeated use of the cell wall fraction for hydrolysis of peptides

The repeated use of the cell wall fraction for hydrolysis of peptides was examined using the peptide mixture prepared from casein described above (the degree of hydrolysis of casein was $10 \%$ ). The suspension of $140 \mathrm{mg}$ of the cell wall fraction in $8 \mathrm{ml}$ of the peptide mixture was incubated at $30^{\circ} \mathrm{C}$ under a few drops of toluene. After $20 \mathrm{hr}$ incubation, the hydrolysis degree of the substrate reached $20 \%$ when the cell wall fraction was recovered by centrifugation washing with $0.05 \mathrm{M}$ acetate buffer, $\mathrm{pH}$ 5.6. The washed cell wall fraction was added to another $8 \mathrm{ml}$ of the peptide mixture to incubate again under the same conditions. The repeated use of the cell wall fraction by this procedure could be done as many as 25 times without any loss of the enzyme activity.

Action of the cell wall fraction on various peptides and effects of zinc ions and EDTA on the enzyme action

The action of the cell wall fraction on various synthetic peptides was examined with or wthi- 
out $2 \mathrm{~mm} \mathrm{Zn}^{2+}$ (acetate) or $2 \mathrm{~mm}$ EDTA. In the experiment, the increase in the amino groups of the reaction mixture was determined. The hydrolysis products were also examined by thin layer chromatography (TLC).

As shown in Table IV, the cell wall fraction displayed high activities on all the synthetic peptides used in the presence of $\mathrm{Zn}^{2+}$. On the other hand, the activities were low in the presence of EDTA. The most striking difference between the two conditions was the action on Leu. Gly $\cdot$ Phe. The hydrolysis of this peptide was achieved only in the presence of $\mathrm{Zn}^{2+}$.

Another interesting finding was that the reaction mixture with $\mathrm{Zn}^{2+}$ produced free Glu from Z-Glu $\cdot$ Phe and Z-Glu.Tyr in addition to free Phe or Tyr. Further, in the presence of $\mathrm{Zn}^{2+}$ the cell wall fraction hydrolysed various carbobenzoxy amino acids such as Z-Glu, Z-Asp, Z-Gln and Z-Ala. However, no such activities were observed in the presence of EDTA.

TABle IV. Activities* on Various SYNTHETIC PEPTIDES

One $\mu \mathrm{mol}$ substrate in $0.05 \mathrm{M}$ acetate buffer, $\mathrm{pH}$ 5.6 , was incubated with $5 \sim 10 \mathrm{mg}$ of the cell wall fraction in total $1.0 \mathrm{ml}$ at $30^{\circ} \mathrm{C}$ for $4 \mathrm{hr}$. The enzyme assay was the same as described in the text.

\begin{tabular}{lccl}
\hline \multicolumn{1}{c}{ Substrates } & None & $\begin{array}{c}\text { Additions } \\
\text { EDTA }\end{array}$ & $\mathrm{Zn}^{2+}$ \\
\hline Z-Glu·Phe & 0.55 & 0.52 & $0.69^{a}$ \\
Z-Phe·Tyr & $-{ }^{6}$ & 0.70 & 0.76 \\
Z-Tyr·Glu & - & 0.51 & 0.56 \\
Z-Glu·Tyr & 0.40 & 0.39 & $0.49^{a}$ \\
Z-Gly·Leu & - & 0.33 & 0.32 \\
Z-Gly·Ile & - & 0.25 & 0.26 \\
Z-Gly·Phe & - & 0.18 & 0.18 \\
Z-Gly·Gly & - & 0.05 & 0.05 \\
Z-Gly·Pro & - & 0.01 & 0.01 \\
Bz-Gly·Arg & - & 0.24 & 0.24 \\
Bz-Gly· Lys & - & 0.24 & 0.24 \\
Bz-Gly·Phe & - & 0.22 & 0.23 \\
Leu·Gly·Phe & 0.03 & 0 & 0.21 \\
\hline
\end{tabular}

* Units per $\mathrm{g}$ cell wall fraction.

a Released free Glu.

$b$ not determined.

Action on oxidized bovine insulin B-chains in the presence of $\mathrm{Zn}^{2+}$ or EDTA

Ten $\mathrm{mg}$ of the cell wall fraction and $0.1 \mu$ - mol of oxidized insulin B-chain were incubated with $5 \mathrm{~mm} \mathrm{Zn}^{2+}$ (acetate) or $5 \mathrm{~mm}$ EDTA in total $1.0 \mathrm{ml}$ at $\mathrm{pH} 5.6$ and $30^{\circ} \mathrm{C}$. At certain time intervals, $0.1 \mathrm{ml}$ aliquots of the mixture were taken into $1.0 \mathrm{ml}$ of distilled water, the mixture was centrifuged, and the supernatant was analyzed for free amino acids by TLC and with amino acid autoanalyzer (Hitachi 835). In the presence of EDTA, Ala appeared in $2 \mathrm{hr}$ and Lys, in $4 \mathrm{hr}$, and their amounts after $24 \mathrm{hr}$ incubation amounted to 0.10 and $0.095 \mu \mathrm{mol}$, respectively. Pro and Thr were produced slightly, but no other amino acids were not observed.

On the other hand, the hydrolysis of oxidized insulin in the presence of $\mathrm{Zn}^{2+}$ by the fraction proceeded further and nearly $10 \mu \mathrm{mol}$ as amino groups were produced among them were $0.2 \mu \mathrm{mol}$ of $\mathrm{Ala}$, indicating that in the presence of $\mathrm{Zn}^{2+}$ certain other proteolytic enzymes than carboxypeptidase-like enzyme acted.

\section{DISCUSSION}

It is certain that several proteolytic enzymes were in the cell wall fraction used in the present paper. This fact was clearly shown when the fraction was incubated with several synthetic peptides in the presence of $\mathrm{Zn}^{2+}$ or EDTA. As shown in Table IV, the cell wall fraction released glutamic acid from Z-Glu Phe and $\mathrm{Z}$-Glu. Tyr in the presence of $\mathrm{Zn}^{2+}$. This activity was observed again on Z-Glu, Z-Gln and Z-Asp in the presence of $\mathrm{Zn}^{2+}$, though no activity was shown on Z-Gly. Also, the cell wall fraction liberated Leu from Leu Gly Phe in the presence of $\mathrm{Zn}^{2+}$, but it did not hydrolyse this substrate at all in the presence of EDTA.

Nevertheless, it was interesting that in the presence of EDTA, the cell wall fraction displayed only carboxypeptidase-like activity. In the hydrolysis of proteins, however, the effect of $\mathrm{Zn}^{2+}$ or EDTA was not as clear as was observed on synthetic peptides, though the degrees and rates of hydrolysis of proteins by the cell wall fraction were greatly improved by previous or simultaneous incubation with 
proteinase, according to the kind of protein as substrate.

It is highly probable that the proteolytic enzymes were covalently bound to the cell wall. Because, the enzyme activities of the cell wall fraction were solubilized to some extent by incubating with "Zymolyase", a yeast cell lytic enzyme preparation. Several other enzyme preparations which showed similar enzyme activities to "Zymolyase" were not effective. Also, treatment of the cell wall fraction with surface active agents or by disruption with cell mill or freezing and thawing method were not effective for dissolution of the enzymes.

The cell wall fraction was applied for repeated use as enzyme preparation. It was thus found that the enzyme activities were maintained even after used 25 times.

Studies on clarifying the enzymic composition, the binding mode and physiological significance of the proteolytic enzymes bound to the cell wall fraction will be subjected to future study.

\section{REFERENCES}

1) R. Hayashi, S. Moore and W. H. Stein, J. Biol. Chem., 248, 2296 (1973).

2) T. Masuda, R. Hayashi and T. Hata, Agric. Biol. Chem., 39, 499 (1975).

3) T. B. Griffin, F. W. Wagner and J. M. Prescott, J. Chromatogr., 23, 280 (1966).

4) T. Nakanishi, Y. Matsumura, N. Minamiura and T. Yamamoto, Agric. Biol. Chem., 38, 37 (1974).

5) E. W. Yemm and E. C. Cocking, Analyst, 80, 209 (1955).

6) K. Kitamura, T. Kaneko and Y. Yamamoto, Arch. Biochem. Biophys., 145, 402 (1971).

7) K. Kitamura, T. Kaneko and Y. Yamamoto, $J$. Gen. Appl. Microbiol., 18, 57 (1972).

8) K. Kitamura and Y. Yamamoto, Arch. Biochem. Bioplys., 153, 403 (1972).

9) M. Dubois, K. A. Guilles, J. K. Hamilton, P. A. Revers and F. Smith, Anal. Chem., 28, 350 (1956). 